\title{
建物清掃における作業環境特性と業務災害の要因に関する研究 A STUDY ON THE CHARACTERISTICS OF WORKING ENVIRONMENTS AND ACCIDENT FACTORS IN CLEANING WORKS OF BUILDINGS
}

\author{
杉田＼cjkstart洋*, 近藤貴 道** \\ Hiroshi SUGITA and Takamichi KONDO
}

\begin{abstract}
This research focuses on cleaning works as one type of building maintenance works, and aims to identify the factors that trigger industrial accidents, through monitoring the current state on the working environment of cleaning workers and its relationship to their physical burden. Specifically, this paper clarifies the working environment of the cleaning workers, based on the results of the survey of multiple buildings that outsource cleaning work to building maintenance service companies. In addition, the characteristics of working environments are categorized into three groups of "Former Middle Facilities", "New Small Facilities" and "Large Facilities", in line with the working environments and facility characteristics of the buildings surveyed. This is followed by a survey on the physical burden of the buildings in each categorized group. Psychiatry, physical fatigue, industrial accidents and the experience of risks those have the possibility of triggering industrial accidents are analyzed for each group, to identify the relationship between the working environment and the physical burden.
\end{abstract}

Keywords : cleaning of buildings, characteristics of working environments, accident factors 建物清掃, 作業環境の特性, 災害要因

1. 序

「建築物における衛生的環境の確保に関する法律」が昭和 45 年 に制定されたことを受け、建物の衛生管理に直接携わるプロフェッ ショナルが必要不可欠になっている。またビルメンテナンス業を専 門とする企業増加に伴い、そこでの就労者数も大幅に増加している。 ビルメンテナンス業者の主要業務としては、清掃業務、警備業務、 設備保全業務などが挙げられる。このうち清掃業務に従事する就労 者は全体の約 6 割を占め、その勤続年数はさほど長くないのが現状 である。全国ビルメンテナンス協会（以下、「協会」と記す）の労働 災害業種別報告 ${ }^{1)}$ および文献 ${ }^{2)}$ では、業務作業中に発生する事故の うち、約 4 割が転倒、約 2 割が墜落・転落であり、これらの大半は 清掃作業中に発生していることが明らかにされている。

しかしながら既往では、災害発生の一要因と考えられる作業環境 の実態と業務災害発生の関係については論じられておらず、業務災 害の発生抑制をはかるためには、これらの関係を明らかにする必要 があると考える。

本研究では、ビルメンテナンス業のなかでも清掃業務に焦点をあ て、ビルメンテナンス業者が清掃業務を実施する建物（以下、「調査 対象建物」と記す）の概要等の把握から、清掃作業環境の実態を示 したうえで、作業環境特性により建物を類型化する。さらに類型化
されたそれぞれの作業環境における、精神的、身体的な作業員負荷 を明らかにしたうえで、清掃作業中に発生する業務災害およびそれ を誘発する可能性のある危険な経験 (以下、「ヒヤリハット」と記す) の関連について分析を進め、業務災害の発生抑制について検討寸る 際に必要となる知見を得ることを目的とする。

本研究の構成を図 1 に示すが、第 1 段階の検討として、実際にど のような作業環境で業務が行われているのかについて明らかにする ために、政令指定都市を有する某県のビルメンテナンス業者を対象 として、「I．清掃作業環境に関する調査」を実施し、「II．清掃作 業環境の実態把握」をする。その結果より「III．作業環境特性によ る調查対象建物の類型化」を行う。

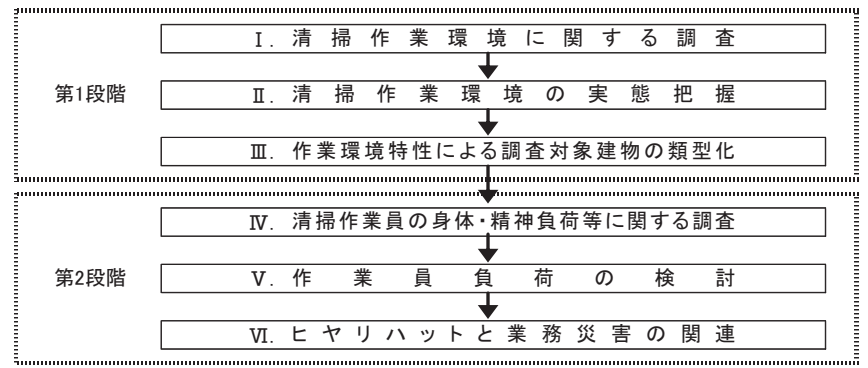

図 1 本研究の構成
* 広島工業大学環境学部 准教授・博士 $($ 工学 $)$

**広島工業大学大学院工学系研究科 大学院生・修士(環境学)
Assoc. Prof., Faculty of Environmental Studies, Hiroshima Institute of Technology, Dr. Eng. Graduate Student, Graduate School of Science and Technology, Hiroshima Institute of Technology, M. Env. 
第 2 段階の検討として、類型化されたグループごとに「IV．清掃 作業員の身体・精神負荷等に関する調查」を実施し、それぞれのグ ループについて、分析対象となる清掃作業員において、身体・精神 負荷を感じている人の割合を体感者率と定義し、これに基づき「V. 作業員負荷の検討」を行う。さらに、建物清掃における業務災害の 発生抑制を目的として実施する「VI．ヒヤリハットと業務災害の関 連」についての分析では、分析対象となる各清掃場所において、ヒ ヤリハットおよび業務災害に遭遇した清掃作業員の割合を遭遇者率 として定義して、両遭遇者率の関連について分析する。

\section{2. 清掃作業環境に関する調査の概要}

\section{1 アンケート調査の概要}

調查は 2006 年 9 月、某県の協会をとおして、同県のビルメンテ ナンス業者 70 業者に回答を依頼し、10月末に回収した。なお、回 答が得られた業者は 30 業者であり、計 242 物件のデータを得た。

アンケートの内容は、受託建物の(1)「建物概要に関する質問」、(2) 「控室の概要に関する質問」、(3)「契約に関する質問」、(4)「作業ス ケジュールに関する質問」の 4 分類 28 項目からなる。各分類にお ける具体的な設問内容を表 1 に示す。なおアンケートの内容は、調 查協力を依頼した協会と協議のうえ決定している。

(1)「建物概要に関する質問」建物の規模や立地に加え、転倒事 故誘発の一要因であると考えられる主要な床仕上げ材について回答 を求める。

(2)「控室の概要に関寸る質問」受託建物における清掃作業員用 控室の有無について回答を求める。さらに控室が有る場合には、電 気・水道といった設備の整備状況について回答を求め、控室が無い 場合は控室の必要性や、具体的な代替場所について回答を求める。

(3)「契約関係に関する質問」 契約年数や継続契約年数などの契

表 1 アンケートの設問内容

\begin{tabular}{|c|c|c|c|}
\hline \multicolumn{2}{|c|}{ 質問項目 } & \multicolumn{2}{|c|}{ 具体的項目 } \\
\hline \multirow{6}{*}{\multicolumn{2}{|c|}{ (1)建物概要 }} & 名称 & 敷地面積 \\
\hline & & 所在地 & 建築面積 \\
\hline & & 竣工年月日 & 延床面積 \\
\hline & & 建物用途 & 管理主体 \\
\hline & & 主要な構造の種類 & 主要な床仕上げ材 \\
\hline & & 階数 & 清掃作業員駐車場の有無 \\
\hline \multirow{8}{*}{ (2)控室の概要 } & \multirow{6}{*}{ 「有り」の場合 } & 控室の数 & \\
\hline & & 控室の構成 & \\
\hline & & 控室の面積 & \\
\hline & & 電気・水道·空の有 & \\
\hline & & 控室に専用の資材厔 & \\
\hline & & 控室に空気調和設价 & \\
\hline & \multirow{2}{*}{ 「無し」の場合 } & 今後の控室の必要 & \\
\hline & & 控室の代わりに使っ & 所(代替場所) \\
\hline \multirow{6}{*}{\multicolumn{2}{|c|}{ (3)契約関係 }} & \multicolumn{2}{|c|}{ 契約年数 } \\
\hline & & \multicolumn{2}{|c|}{ 継続契約年数 } \\
\hline & & \multicolumn{2}{|c|}{ リニューアルエ事完了年月日 } \\
\hline & & \multicolumn{2}{|c|}{ 清掃業務以外で委託を受けている業務の有無 } \\
\hline & & \multicolumn{2}{|c|}{ 空気調和設備等の使用について } \\
\hline & & \multicolumn{2}{|c|}{ 屋外空間の清掃業務受注の有無 } \\
\hline \multirow{2}{*}{\multicolumn{2}{|c|}{ (4)作業スケジュール }} & \multicolumn{2}{|c|}{ 日常清掃を実施する曜日 } \\
\hline & & \multicolumn{2}{|c|}{$\begin{array}{l}\text { 代表的な1日のスケジュール(清掃作業時間帯)と } \\
\text { その時間带の作業人員 }\end{array}$} \\
\hline
\end{tabular}

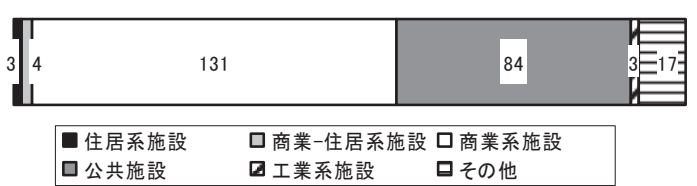

図 2 用途区分による分類（件）
約期間について回答を求める。また、契約書に記載されている作業 時の空調利用の可否などにあわせ、屋外清掃の受託状況についても 回答を求める。

(4)「作業スケジュールに関する質問」作業を実施している曜日 や時間帯、および代表的な 1 日のスケジュール（清掃作業時間帯） とその時間帯の作業人員について回答を求める。

\section{2 調査対象建物の概要}

調査により得られた 242 物件を用途区分により分類した。結果を 図 2 に示す。なおここでは、文献 ${ }^{3)}$ による用途区分を参考とし、242 物件を「住居系施設」「商業-住居系施設」「商業系施設」「公共施設」 注1)「工業系施設」「その他」に分類している。

図 2 をみるならば、6 分類のなかでも「商業系施設」「公共施設」 が全体の 8 割強を占めていることがわかる。

さらに、竣工年と延床面積を把握するため、横軸に竣工年、縦軸 に延床面積をとり、各建物を布置した。結果を図 3 に示す。なお、 図 2 に示したとおり、「住居系施設」「商業-住居系施設」「工業系施 設」「その他」の物件数は少ないことから、図 3 においてはこれら の施設を「その他の施設」として布置している。

図 3 によれば、対象建物の竣工年数は 1930 年代〜 2000 年代に幅 広く分布しているが、1990 年代に建設された物件が全体の約 4 割 を占める。延床面積では、10,000 m²前後に集中している。

\section{3. 作業環境特性による調査対象建物の類型化}

ここでは、建物の特性および作業環境特性から建物を類型化する ため、表 1 に示したアンケート調査項目のなかでも、作業環境特性 を表し、かつサンプル数に偏りが小さい 10 項目についてす心゙て回 答が得られた 124 建物に対して、数量化理論第正類による解析を適 用した。10 項目の内容を表 2 に、最大固有值とつぎに大きな固有值 を第 I 軸、第 II 軸として各カテゴリーを布置した結果を図 4 に示す。

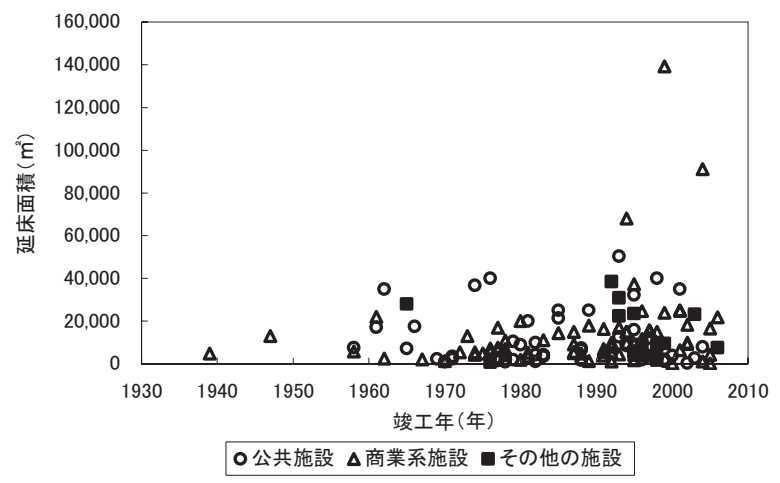

図 3 竣工年と延床面積との関連

表 2 数量化理論第III類に適用寸る項目とその集計結果

\begin{tabular}{|c|c|c|}
\hline アイテム & カテゴリー & サンプル数 \\
\hline \multirow{2}{*}{ 竣工年代 } & 1989年以前 & 58 \\
\hline & 1990年以降 & 66 \\
\hline \multirow{2}{*}{ 階数 } & 5階以下 & 65 \\
\hline & 6階以上 & 59 \\
\hline \multirow{2}{*}{ 延床面積 } & $10,000 \mathrm{~m}^{2}$ 未満 & 79 \\
\hline & $10,000 \mathrm{~m}^{2}$ 以上 & 45 \\
\hline \multirow{2}{*}{ 駐車場の有無 } & 有り & 26 \\
\hline & \begin{tabular}{|l|} 
無L \\
\end{tabular} & 98 \\
\hline \multirow{2}{*}{ 控室の有無 } & 有り & 97 \\
\hline & \begin{tabular}{|l|} 
無L \\
\end{tabular} & 27 \\
\hline
\end{tabular}

\begin{tabular}{l|l|c}
\hline \multicolumn{1}{c}{ アイテム } & カテゴリー & サンプル数 \\
\hline \multirow{2}{*}{ 屋外清掃の受注 } & 有り & 95 \\
\cline { 2 - 3 } & 無 & 29 \\
\hline \multirow{2}{*}{ 空気調和設備等の使用稼動 } & 87 \\
\cline { 2 - 3 } & 使用禁止 & 37 \\
\hline \multirow{2}{*}{ 清掃実施曜日 } & 毎日 & 43 \\
\cline { 2 - 3 } & 日曜以外 & 51 \\
\cline { 2 - 3 } & 平日 & 30 \\
\hline \multirow{2}{*}{ 1時間あたり作業人員 } & 3人/時未満 & 70 \\
\cline { 2 - 3 } & 3人/時以上 & 54 \\
\hline \multirow{2}{*}{ 1日合計作業時間 } & 6時間未満 & 31 \\
\cline { 2 - 3 } & 6時間以上 & 93 \\
\hline
\end{tabular}


図 4 をみるならば、第 I 軸は「延床面積」のカテゴリーが軸に沿 って布置されており、正側に $10,000 \mathrm{~m}^{2}$ 以上の建物、負側に 10,000 $\mathrm{m}^{2}$ 未満の建物が類別されている。これに対応して他のカテゴリーと 併せて解釈するならば、前者は「控室」があり、「1 時間あたりの作業 人員」が 3 人以上、 11 日の合計作業時間 $」$ が 6 時間以上の「大規模型」 であり、後者は「控室」がなく、「1 時間あたりの作業人員」が 3 人未 満、「1 日の合計作業時間」が 6 時間未満の「小規模型」であると解勫 できる。

第 II 軸は「竣工年」との関連がみられ、他のカテゴリーと併せて解 釈するならば、正側は 1989 年以前の竣工であり、駐車場」がない「昭 和型」、負側は 1990 年以降の竣工であり、「駐車場」がある「平成型」 の建物であると解釈できる。

さらに本研究では、既往研究 ${ }^{4)}$ にて適用した分析手法に基づき、 第 I 軸および第 II 軸のサンプルスコアを用いて、ウォード法による クラスター分析を適用した。結果をサンプルスコアの布置と併せて 図 5 に示す。

分析対象である 124 建物は、大きく 3 つのグループに分類される ことから、本研究では建物の特性および作業環境特性により、各グ ループをそれぞれ「(1)旧中規模建物」「(2)新小規模建物」「(3)大規模 建物」と定義する。

\section{4. 清掃作業員の身体・精神負荷等に関する調査の概要} 4.1 調査対象建物の概要

ここでは、前章の類型に基づき、グループ(1)：「旧中規模建物」に 含まれる 3 建物、グループ(2):「新小規模建物」に含まれる 3 建物、 グループ(3)：「大規模建物」に含まれる 5 建物の計 11 建物を分析対 象とする注2)。表 3 に各建物の概要を示す。
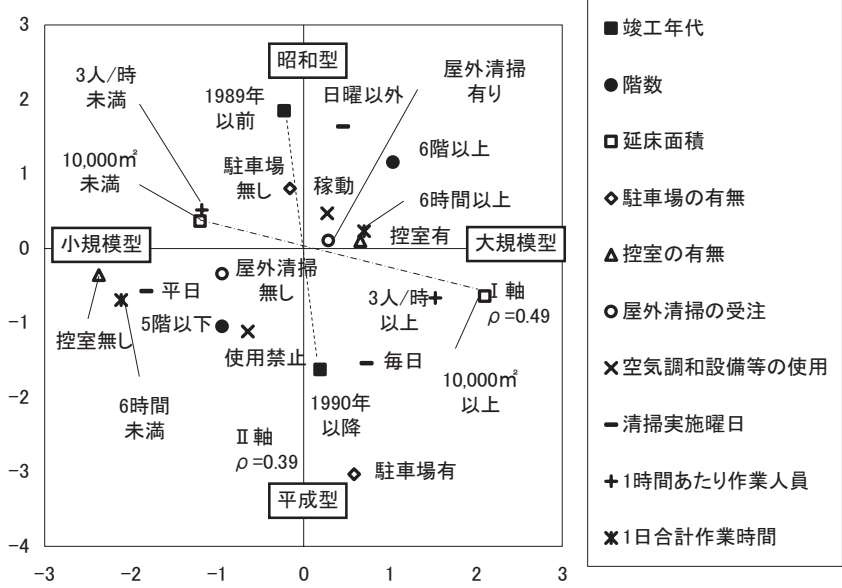

図 4 数量化理論第III類による分析結果

\section{2 ヒアリング調査の概要}

ヒアリング調查は、 2007 年 8 月下旬から 12 月下旬にかけて、協 会をとおしてビルメンテナンス業者に依頼し、調査対象建物の清掃 作業員に対し面接形式により実施した。なお、各グループにおける 回答者数は、グループ(1)で 8 人、グループ(2)で 4 人、グループ(3)で 20 人の計 32 人である。

ヒアリング調査の内容は、(1)「対象建物に関する質問」、(2)「清掃 作業時間に関する質問」、(3)「作業スケジュールに関する質問」、(4) 「清掃業務災害に関する質問」、(5)「ヒヤリハットに関する質問」、 (6)「疲労に関寸る質問」、(7)「現在の担当物件に関寸る質問」、(8)「今 までの経験に関する質問」、(9)「属性に関する質問」の 9 分類で構 成され、40 頁 37 項目からなる。ヒアリングの質問内容を表 4 に示 す。なおヒアリング調查の内容は、調查協力を依頼した協会と協議 のうえ決定している。

(1)「対象建物に関する質問」 清掃作業中にエレベーターが利用 できるか、リニューアル工事の有無と工事内容、リニューアル工事 前後で清掃作業のしやすさの違いについて回答を求める。

(2)「清掃作業時間に関する質問」＼cjkstart清掃場所ごとに作業時間が決 められているか尋ね、決められていると回答した人に対しては、各 清掃場所に設定されている作業時間と、その適正について回答を求 める。

(3)「作業スケジュールに関する質問」作業を実施している曜日 および時間帯、また担当している清掃作業の内容について回答を求 める。

(4)「清掃業務災害に関する質問」業務災害の遭遇の有無、災害 場所、作業箇所、作業種類、災害の種類、ケガの種類について回答 を求める。

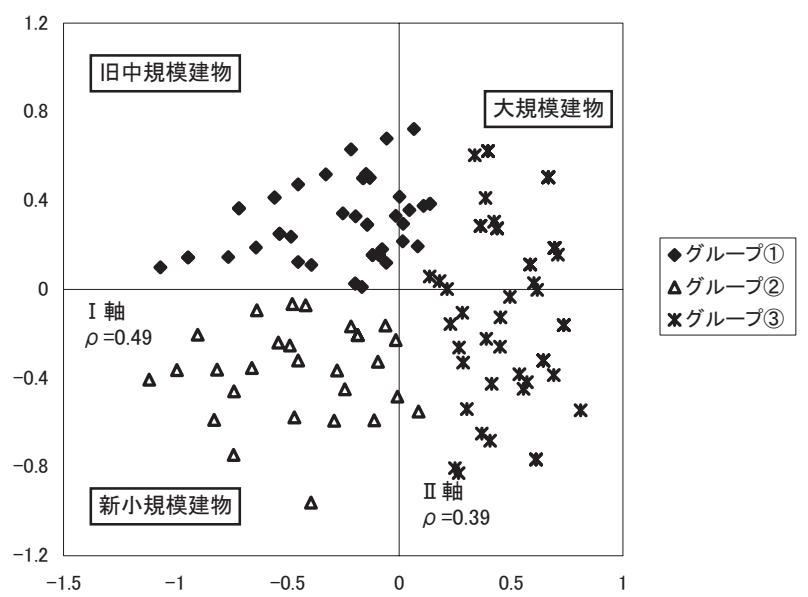

図 5 サンプルスコアの布置

表 3 建物の概要

\begin{tabular}{|c|c|c|c|c|c|c|c|c|c|c|c|c|}
\hline \multirow{2}{*}{ グループ } & \multirow{2}{*}{ 建物No. } & \multicolumn{5}{|c|}{ 建物概要 } & \multicolumn{2}{|c|}{$\begin{array}{l}\text { 作業環境 } \\
\end{array}$} & \multicolumn{4}{|c|}{ 作業状況 } \\
\hline & & 建物用途分類 & 竣工年 & 階数 & 主要な構造 & 延床面積 $\left(\mathrm{m}^{2}\right)$ & 控室 & 空調 & 実施日/週 & 作業時間帯 & 作業時間 & 作業員数 \\
\hline \multirow{3}{*}{ (1) } & 1 & 業務施設 & 1995 & 地上10階地下2階 & $\mathrm{S}$ & 9,596 & $\begin{array}{l}\text { 無 } \\
\end{array}$ & $\mathrm{O}$ & 6 & 7時〜16時 & 9 & 4 \\
\hline & 2 & 官公庁施設 & 1958 & 地上4階地下1階 & \begin{tabular}{|l|l} 
無回答 \\
\end{tabular} & 7,493 & 有 & 0 & 6 & 7時〜22時 & 14 & 2 \\
\hline & 3 & 官公庁施設 & 1988 & 地上3階地下 1 階 & SRC & 7,383 & 有 & 0 & 6 & 8時 17時 & 8 & 2 \\
\hline \multirow{3}{*}{ (2) } & 4 & 商業施設 & 1996 & 地上4階 & $\mathrm{RC}$ & 5,014 & 無 & 0 & 7 & 7時 11時 & 4 & 2 \\
\hline & 5 & 商業施設 & 1996 & 地上5階 & $\mathrm{RC}$ & 2,400 & 有 & 0 & 7 & 7 時 11時 & 4 & 1 \\
\hline & 6 & 業務施設 & 2000 & 地上2階 & $\mathrm{RC}$ & 528 & 無 & 0 & 3 & 7時〜14時 & 6 & 1 \\
\hline \multirow{5}{*}{ (3) } & 7 & 商業施設 & 1961 & 地上11階地下2階 & $\mathrm{RC}$ & 21,960 & 有 & $\mathrm{O}$ & 7 & 7時 12時 & 5 & 6 \\
\hline & 8 & 業務施設 & 1996 & 地上20階 & $\mathrm{RC}$ & 24,752 & 有 & $\mathrm{O}$ & 6 & 7時～10時 & 3 & 2 \\
\hline & 9 & 官公庁施設 & 1993 & 地上4階地下 1 階 & $\mathrm{RC}$ & 12,560 & 有 & 0 & 6 & 7時 18時 & 11 & 3 \\
\hline & 10 & 業務施設 & 1974 & 地上8階地下2階 & $\begin{array}{l}\text { 無回答 } \\
\end{array}$ & 36,648 & 有 & $\mathrm{O}$ & 6 & 12時～6時 & 16 & 2 \\
\hline & 11 & 文教厚生施設 & 2004 & 地上6階 & $\mathrm{RC}$ & 8,000 & 有 & $\mathrm{O}$ & 6 & 12時 6時 & 17 & 7 \\
\hline
\end{tabular}


(5)「ヒヤリハットに関する質問」ヒヤリハットの遭遇の有無、 ヒヤリハットに遭遇した場所、作業箇所、作業種類、ヒヤリハット の種類について回答を求める。さらに可能であれば、遭遇時の就労 年数等についても回答を求める。

(6「疲労に関する質問」清掃場所ごとの精神的な疲労について、 「どこの」「どのような作業」をしている時に、「何が」「どうだから」 精神的な疲労を感じるのかについて回答を求める。同様に身体的な 疲労についても「どこの」「どのような作業」をしている時に「身体 のどの部位が」「どうなる」から疲労を感じるか回答を求める。

(7)「現在の担当物件に関寸る質問」対象建物以外に、清掃に従 事している物件の有無と物件数について回答を求める。

(8)「今までの経験に関する質問」今までに担当した建物のなか で、「作業を実施しやすい建物用途」と「実施しにくい建物用途」に ついて尋㸚、その理由についてもあわせて回答を求める。

（9「属性に関する質問」個人特性（性別、年齢、身長・体重、 利き手、喫煙、食事、起床時刻・平均睡眠時間、持病、専門職種、 就労年数、業務時間帯、出社頻度）について回答を求める。

\section{3 回答者属性}

各グループにおける回答者属性をそれぞれ表 5 に示す。

「性別」では、グループ(1)：「旧中規模建物」、(2)：「新小規模建物」 は女性のみであり、グループ(3) :「大規模建物」で男性が 2 割を占 める。「年齢」では、グループ(1)、(2)において 60 歳以上が過半を占 めるが、グループ(3)では 60 歳未満が 6 割以上を占めている。ちな みに平均年齢では、グループ(1) 60.75 歳、グループ(2)58.75 歳、グ ループ(3)54.15 歳となっており、グループ(3)が最も若い。「身長」で

\begin{tabular}{|c|c|}
\hline 質問分類 & \begin{tabular}{|c|} 
質問項目 \\
\end{tabular} \\
\hline \multirow{5}{*}{ 対象建物 } & 清掃中のエレベーターの利用 \\
\hline & リニューアルエ事の有無 \\
\hline & 工事場所、工事内容、工事前、工事後 \\
\hline & リニューアルエ事前後の清掃作業の行いやすさ \\
\hline & リニューアルエ事前後が清掃作業を行いやすい理由 \\
\hline \multirow{2}{*}{ 清掃作業時間 } & 清掃場所ごとに作業時間が決められているか \\
\hline & 各清掃場所で決められている時間、時間の適正 \\
\hline \multirow{2}{*}{ 作業スケジュール } & 作業周期 \\
\hline & 各曜日の勤務時間、清掃場所、作業内容 \\
\hline \multirow{3}{*}{ 清掃業務災害 } & 業務災害の遭遇の有無 \\
\hline & 災害場所、作業箇所、作業種類、災害の種類、ケガの種類 \\
\hline & 就労年数、日時、天候、空調、理由注)、床仕上げ \\
\hline \multirow{3}{*}{ ヒヤリハット } & ヒヤリハットの遭遇の有無 \\
\hline & 遭遇場所、作業箇所、作業種類、ヒヤリハットの種類 \\
\hline & 就労年数、日時、天候、空調、理由注)、床仕上げ \\
\hline \multirow{6}{*}{ 疲労 } & 作業の有無 \\
\hline & 精神的疲労を感じるか \\
\hline & 精神的疲労の要因 \\
\hline & 身体的疲労を感じるか \\
\hline & 身体的疲労の要因 \\
\hline & 疲労部位と疲労の度合い \\
\hline \multirow{2}{*}{ 現在の担当物件 } & 対象建物以外の清掃に従事している物件の有無 \\
\hline & 対象建物以外の物件数 \\
\hline \multirow{2}{*}{ 今までの経験 } & 清掃作業を行いやすい建物とその理由 \\
\hline & 清掃作業を行いにくい建物とその理由 \\
\hline \multirow{12}{*}{ 属性 } & 性別 \\
\hline & 年齢 \\
\hline & 身長·体重 \\
\hline & 利き手 \\
\hline & 契煙 \\
\hline & 食事 \\
\hline & 起床時間·平均睡眠時間 \\
\hline & 持病 \\
\hline & 専門職種 \\
\hline & 就労年数 \\
\hline & 業務時間帯 \\
\hline & 出社頻度 \\
\hline
\end{tabular}

は、すべてのグループで $155 \mathrm{~cm}$ 未満が過半を占めており、「体重」 では、グループ11、(3)において $60 \mathrm{~kg}$ 未満が過半を占め、グループ (2)では同比である。「利き手」では、すべてのグループで右利きの割 合が高く、「喫煙」では 8 割以上が吸わないと回答している。「朝食」 では、摂っている人が大半であり、「起床時刻」を全体でみるならば 5 時以降に起床寸る人の割合が高いものの、グループ(1)では 6 割以 上の人が 5 時より前に起床している。「睡眠時間」では、全体の半数 以上が 6 時間以上である。また「持病」の有無では、6 割以上が無い と回答している。

「専門職種」では、パートタイマーが 6 割以上を占め、「清掃業務 就労年数」では 5 年未満と 5 年以上がほぼ同比である。また「対象建 物就労年数」では、 2 年以上が過半を占めている。「業務時間」では、 5 時間未満と 5 時間以上が同比である。

ここで、各グループにおける清掃作業員の特徵を整理すると、グ ループ(1)では、非喫煙者で持病がない女性により作業が実施されて おり、その 7 割は 60 歳以上である。また半数近くの人は、対象建 物以外の清掃業務にも携わっている。グループ(2)、非喫煙者で右 利きの女性、業務時間は 5 時間未満のパートタイマーのみで作業が 実施されている。グループ(3)は、男性と女性、喫煙者と非喫煙者が 混在しており、4 割が正社員であり、清掃業務就労年数では半数が 5 年未満であるが、業務時間では 6 割が 5 時間以上と、他のグルー プと比較して長時間作業を実施している。またこのグループの 7 割 の人は、対象建物以外の清掃業務にも携わっている。

\section{4 各グループにおける作業の実施状況}

グループ(1)、(2)、(3)それぞれの各清掃場所注 3) における清掃作業 の実施者率注 4) を算出した。結果を表 6 に示す。表の見方として、

表 5 回答者属性

\begin{tabular}{|c|c|c|c|c|c|}
\hline \multirow{2}{*}{ アイテム } & \multirow{2}{*}{ カテゴリー } & \multicolumn{3}{|c|}{ グループNo. } & \multirow{2}{*}{ 合計 } \\
\hline & & (1) & (2) & (3) & \\
\hline \multirow{2}{*}{ 性別 } & 男性 & 0 & 0 & 5 & 5 \\
\hline & 女性 & 8 & 4 & 15 & 27 \\
\hline \multirow{2}{*}{ 年齢 } & 60歳未満 & 2 & 1 & 13 & 16 \\
\hline & 60歳以上 & 6 & 3 & 7 & 16 \\
\hline \multirow{2}{*}{ 身長 } & 155cm未満 & 5 & 3 & 12 & 20 \\
\hline & $155 \mathrm{~cm}$ 以上 & 3 & 1 & 8 & 12 \\
\hline \multirow{2}{*}{ 体重 } & 60kg未満 & 7 & 2 & 13 & 22 \\
\hline & $60 \mathrm{~kg}$ 以上 & 1 & 2 & 7 & 10 \\
\hline \multirow{3}{*}{ 利き手 } & 右利き & 7 & 4 & 17 & 28 \\
\hline & 左利き & 1 & 0 & 2 & 3 \\
\hline & 両方 & 0 & 0 & 1 & 1 \\
\hline \multirow{2}{*}{ 喫煙 } & 吸う & 0 & 0 & 5 & 5 \\
\hline & 吸わない & 8 & 4 & 15 & 27 \\
\hline \multirow{2}{*}{ 食事 } & 朝食摂っている & 7 & 4 & 13 & 24 \\
\hline & 朝食捖っていない & 1 & 0 & 7 & 8 \\
\hline \multirow{2}{*}{ 起床時間 } & 5時より前 & 5 & 0 & 5 & 10 \\
\hline & 5時以降 & 3 & 4 & 15 & 22 \\
\hline \multirow{3}{*}{ 睡眠時刻 } & 6時間未満 & 3 & 1 & 6 & 10 \\
\hline & 6時間以上 & 4 & 3 & 14 & 21 \\
\hline & 無回答 & 1 & 0 & 0 & 1 \\
\hline \multirow{2}{*}{ 持病 } & 持病ある & 0 & 3 & 8 & 11 \\
\hline & 持病なし & 8 & 1 & 12 & 21 \\
\hline \multirow{3}{*}{ 専門職種 } & 正社員 & 2 & 0 & 8 & 10 \\
\hline & パートタイマー & 5 & 4 & 12 & 21 \\
\hline & その他(契約社員) & 1 & 0 & 0 & 1 \\
\hline \multirow{2}{*}{ 清掃業務就労年数 } & 5年未満 & 2 & 1 & 11 & 14 \\
\hline & 5年以上 & 6 & 3 & 9 & 18 \\
\hline \multirow{2}{*}{ 対象建物就労年数 } & 2年未満 & 2 & 1 & 8 & 11 \\
\hline & 2年以上 & 6 & 3 & 12 & 21 \\
\hline \multirow{3}{*}{ 業務時間 } & 5時間未満 & 4 & 4 & 7 & 15 \\
\hline & 5時間以上 & 3 & 0 & 12 & 15 \\
\hline & 不定期 & 1 & 0 & 1 & 2 \\
\hline \multirow{2}{*}{ 出社頻度 } & 出社しない & 7 & 1 & 16 & 24 \\
\hline & 出社する & 1 & 3 & 4 & 8 \\
\hline \multirow{2}{*}{ 対象建物以外の清掃 } & 対象建物以外の清掃有り & 3 & 1 & 6 & 10 \\
\hline & 対象建物以外の清掃無し & 5 & 3 & 14 & 22 \\
\hline
\end{tabular}


例えばグループ(1)における「玄関ホール」の欄は $75 \%$ と記されてい るが、これはグループ(1)の作業人数 8 人のうち 6 人が実施している ことを意味している。

表 6 によれば、いずれのグループも「便所及び洗面所」の作業を 実施している人が最も多く、「廊下及びエレベーターホール」「階段」 「玄関ホール」がこれに続く。またグループ(2)では、すべての人が この 4 室の作業を実施しており、建物が小規模になるにつれ、作業 員の清掃範囲が拡大していることがわかる。

\section{5. 作業員負荷の検討}

\section{1 精神的疲労の実態}

グループ (1)、(2)、(3)それぞれにおける清掃場所ごとの精神的疲労 の体感者率注5)を算出した。結果を表 7 に示す。

表 7 に示したグループ(1)列をみるならば、「居室」注3)に対する 指摘が最も多く、6 割の人が精神的疲労を感じており「喫煙スペー ス」「便所及び洗面所」がこれに続く。グループ(2)では、「階段」に おいて 7 割の人が疲労を感じている。またグループ(3)では、「外部

(駐車場等)」にて 7 割の人が疲労を感じていることがわかる。

さらに、何に対して精神的疲労を感じているのかを把握するため に、精神的疲労の要因を整理し、各清掃場所の作業実施者数を分母 として、疲労を感じていると回答した人数の割合を要因別に算出し た。結果を百分率として表 8 に示す。

全体をみるならば、建物利用者への配慮といった「人の存在」や、 落としづらい「污れ」に対して精神的疲労を感じていることがわか る。また、グループ(1)の「玄関ホール」「居室」、グループ(3)の「居 室」では、建物利用者からの清掃品質に対するクレーム「要求品質」 が精神的な疲労の要因として挙げられている。さらにグループ(2)、 (3)の「階段」では、転倒しないように気をつけるなどといった「自 分への配慮」が要因として認められた。

表 6 各グループにおける作業の実施状況

\begin{tabular}{l|r|r|r}
\hline \multirow{2}{*}{ 清掃場所 } & \multicolumn{3}{|c}{ グループNo. } \\
\cline { 2 - 4 } & \multicolumn{1}{|c|}{1} & \multicolumn{1}{c}{ (2) } & \multicolumn{1}{c}{3} \\
\hline 玄関ホール & $75.0 \%$ & $100.0 \%$ & $65.0 \%$ \\
\hline 居室 & $62.5 \%$ & $100.0 \%$ & $60.0 \%$ \\
\hline 食堂 & $37.5 \%$ & $75.0 \%$ & $25.0 \%$ \\
\hline 便所及び洗面所 & $100.0 \%$ & $100.0 \%$ & $80.0 \%$ \\
\hline 湯沸室 & $75.0 \%$ & $75.0 \%$ & $30.0 \%$ \\
\hline エレベーター & $87.5 \%$ & $75.0 \%$ & $50.0 \%$ \\
\hline 階段 & $87.5 \%$ & $100.0 \%$ & $65.0 \%$ \\
\hline 廊下及びエレベーターホール & $87.5 \%$ & $100.0 \%$ & $70.0 \%$ \\
\hline 浴室·脱衣室·シャワールーム & $12.5 \%$ & $50.0 \%$ & $30.0 \%$ \\
\hline 喫煙スペース & $62.5 \%$ & $75.0 \%$ & $35.0 \%$ \\
\hline 外部(駐車場等) & $25.0 \%$ & $50.0 \%$ & $20.0 \%$ \\
\hline その他 & $12.5 \%$ & - & - \\
\hline
\end{tabular}

表 7 精神的疲労の発生状況

\begin{tabular}{|c|c|c|c|}
\hline \multirow{2}{*}{ 清掃場所 } & \multicolumn{3}{|c|}{ グループNo. } \\
\hline & (1) & (2) & (3) \\
\hline 玄関ホール & $33.3 \%$ & $50.0 \%$ & $46.2 \%$ \\
\hline 居室 & $60.0 \%$ & $50.0 \%$ & $25.0 \%$ \\
\hline 食堂 & $33.3 \%$ & $33.3 \%$ & $40.0 \%$ \\
\hline 便所及び洗面所 & $37.5 \%$ & $50.0 \%$ & $31.3 \%$ \\
\hline 湯沸室 & $16.7 \%$ & $33.3 \%$ & - \\
\hline エレベーター & $28.6 \%$ & - & $20.0 \%$ \\
\hline 階段 & $28.6 \%$ & $75.0 \%$ & $38.5 \%$ \\
\hline 廊下及びエレベーターホール & $14.3 \%$ & $50.0 \%$ & $21.4 \%$ \\
\hline 浴室·脱衣室·シャワールーム & - & $50.0 \%$ & $16.7 \%$ \\
\hline 喫煙スペース & $40.0 \%$ & $33.3 \%$ & - \\
\hline 外部(駐車場等) & - & $50.0 \%$ & $75.0 \%$ \\
\hline その他 & - & & \\
\hline
\end{tabular}

\section{2 身体的疲労の実態}

グループ(1)、(2)、(3)それぞれにおける清掃場所ごとの身体的疲労 の体感者率注5)を算出した。結果を表 9 に示寸。

表 9 に示したグループ(1)の列をみるならば、「外部（駐車場）」に 対する指摘の割合が最も多く、身体的疲労を感じている人が全体の 5 割を占める。グループ(2)では、「廊下及びエレベーターホール」で 5 割の人が、グループ(3)では、「外部（駐車場）」で 7 割の人が身体 的疲労を感じていた。またグループ(1)はグループ(2)と比較して身体 的疲労を感じている場所が多く、グループ(3)グループ(1) と比較し て身体的疲労を感じている場所がさらに多い。これは建物規模との 関係であると考えられ、規模の違いによる「作業時間」の長短が身 体的疲労の発生に起因していると考えられる。

\section{6. ヒヤリハットの実態}

グループ（1)、（2、（3)それぞれにおける清掃場所ごとのヒヤリハッ トの遭遇者率注 6) を算出した。結果を表 10 に示す。

表 10 に示したグループ11の列をみるならば、「玄関ホール」「居 室」「便所及び洗面所」「エレベーター」「階段」の 5 箇所にてヒヤ リハットが発生している。グループ(2)では、「居室」「階段」の 2 箇 所で、グループ(3)では、「居室」「食堂」「便所及び洗面所」「階段」 「浴室・脱衣室・シャワールーム」の 5 箇所においてヒヤリハット

表 8 精神的疲労の要因

\begin{tabular}{|c|c|c|c|c|c|c|}
\hline \multirow{2}{*}{ 清掃場所 } & \multicolumn{6}{|c|}{ グループNo. } \\
\hline & (1) & & (2) & & (3) & \\
\hline 玄関ホール & $\begin{array}{c}\text { 人の存在 } \\
\text { 污れ } \\
\text { 要求品質 }\end{array}$ & $\begin{array}{l}17 \% \\
17 \% \\
17 \%\end{array}$ & $\begin{array}{l}\text { 人の存在 } \\
\text { 作業内容 }\end{array}$ & $\begin{array}{l}25 \% \\
25 \%\end{array}$ & $\begin{array}{c}\text { 人の存在 } \\
\text { 污れ } \\
\text { 作業内容 } \\
\text { 時間 }\end{array}$ & $\begin{array}{l}31 \% \\
8 \% \\
8 \% \\
8 \%\end{array}$ \\
\hline 居室 & $\begin{array}{c}\text { 要求品質 } \\
\text { 人の存在 } \\
\text { 污れ } \\
\text { 自分への配慮 } \\
\text { その他 }\end{array}$ & \begin{tabular}{l|}
$60 \%$ \\
$20 \%$ \\
$20 \%$ \\
$20 \%$ \\
$20 \%$
\end{tabular} & 人の存在 & $50 \%$ & $\begin{array}{l}\text { 人の存在 } \\
\text { 作業内容 } \\
\text { 要求品質 } \\
\text { その他 }\end{array}$ & $\begin{array}{l}8 \% \\
8 \% \\
8 \% \\
8 \%\end{array}$ \\
\hline 食堂 & 人の存在 & $33 \%$ & 人の存在 & $33 \%$ & 人の存在 & $40 \%$ \\
\hline 便所及び洗面所 & $\begin{array}{l}\text { 人の存在 } \\
\text { 污れ }\end{array}$ & $\begin{array}{l}25 \% \\
13 \%\end{array}$ & $\begin{array}{l}\text { 人の存在 } \\
\text { 作業内容 }\end{array}$ & $\begin{array}{l}25 \% \\
25 \%\end{array}$ & $\begin{array}{c}\text { 污れ } \\
\text { 人の存在 } \\
\text { 時間 } \\
\text { その他 }\end{array}$ & $\begin{array}{l}19 \% \\
6 \% \\
6 \% \\
6 \%\end{array}$ \\
\hline 湯沸室 & 污れ & $17 \%$ & 人の存在 & $33 \%$ & & \\
\hline エレベーター & $\begin{array}{c}\text { 人の存在 } \\
\text { 污れ }\end{array}$ & $\begin{array}{l}14 \% \\
14 \% \\
\end{array}$ & & & $\begin{array}{c}\text { 人の存在 } \\
\text { 污れ }\end{array}$ & $\begin{array}{l}10 \% \\
10 \%\end{array}$ \\
\hline 階段 & $\begin{array}{c}\text { 人の存在 } \\
\text { 污れ }\end{array}$ & $\begin{array}{l}14 \% \\
14 \%\end{array}$ & $\begin{array}{c}\text { 污れ } \\
\text { 人の存在 } \\
\text { 自分への配慮 }\end{array}$ & $\begin{array}{l}50 \% \\
25 \% \\
25 \%\end{array}$ & $\begin{array}{c}\text { 時間 } \\
\text { 人の存在 } \\
\text { 作業量 } \\
\text { 自への配慮 }\end{array}$ & $\begin{array}{l}15 \% \\
8 \% \\
8 \% \\
8 \%\end{array}$ \\
\hline $\begin{array}{l}\text { 廊下及び } \\
\text { エレベーターホール }\end{array}$ & 污れ & $14 \%$ & $\begin{array}{c}\text { 人の存在 } \\
\text { 污れ }\end{array}$ & \begin{tabular}{r|}
$25 \%$ \\
$25 \%$
\end{tabular} & $\begin{array}{c}\text { 人の存在 } \\
\text { 污れ }\end{array}$ & $\begin{array}{r}14 \% \\
7 \%\end{array}$ \\
\hline $\begin{array}{l}\text { 浴室·脱衣室· } \\
\text { シャワールーム }\end{array}$ & & & 時間 & $50 \%$ & 污れ & $17 \%$ \\
\hline 契煙スペース & 污れ & $40 \%$ & 污れ & $33 \%$ & & \\
\hline 外部(駐車場等) & & & 污れ & $50 \%$ & $\begin{array}{l}\text { 污れ } \\
\text { その他 }\end{array}$ & $\begin{array}{l}50 \% \\
25 \%\end{array}$ \\
\hline
\end{tabular}

表 9 身体疲労の発生状況

\begin{tabular}{|c|c|c|c|}
\hline \multirow{2}{*}{ 清掃場所 } & \multicolumn{3}{|c|}{ グループNo. } \\
\hline & (1) & (2) & (3) \\
\hline 玄関ホール & $16.7 \%$ & - & $38.5 \%$ \\
\hline 居室 & $20.0 \%$ & - & $16.7 \%$ \\
\hline 食堂 & - & - & $20.0 \%$ \\
\hline 便所及び洗面所 & $12.5 \%$ & $25.0 \%$ & $31.3 \%$ \\
\hline 湯沸室 & $16.7 \%$ & - & - \\
\hline エレベーター & - & - & $20.0 \%$ \\
\hline 階段 & $14.3 \%$ & $25.0 \%$ & $53.8 \%$ \\
\hline 廊下及びエレベーターホール & $14.3 \%$ & $50.0 \%$ & $21.4 \%$ \\
\hline 浴室·脱衣室·シャワールーム & - & - & $16.7 \%$ \\
\hline 喫煙スペース & - & - & - \\
\hline 外部(駐車場等) & $50.0 \%$ & - & $75.0 \%$ \\
\hline その他 & - & 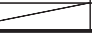 & \\
\hline
\end{tabular}


表 10 ヒヤリハットの遭遇状況

\begin{tabular}{|c|c|c|c|}
\hline \multirow{2}{*}{ 清掃場所 } & \multicolumn{3}{|c|}{ グループNo. } \\
\hline & (1) & (2) & (3) \\
\hline 玄関ホール & $16.7 \%$ & $\begin{array}{ll}- & \\
\end{array}$ & - \\
\hline 居室 & $40.0 \%$ & $25.0 \%$ & $8.3 \%$ \\
\hline 食堂 & \begin{tabular}{l|l}
- & \\
\end{tabular} & - & $20.0 \%$ \\
\hline 便所及び洗面所 & $12.5 \%$ & 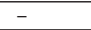 & $6.3 \%$ \\
\hline エレベーター & $14.3 \%$ & 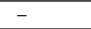 & - \\
\hline 階段 & $14.3 \%$ & $25.0 \%$ & $23.1 \%$ \\
\hline 浴室·脱衣室·シャワールーム & \begin{tabular}{l|l}
- & \\
\end{tabular} & - & $16.7 \%$ \\
\hline
\end{tabular}

表 12 業務災害の発生状況

\begin{tabular}{|c|c|c|c|}
\hline \multirow{2}{*}{ 清掃場所 } & \multicolumn{3}{|c|}{ グループNo. } \\
\hline & (1) & (2) & (3) \\
\hline 玄関ホール & - & $25.0 \%$ & - \\
\hline 居室 & $40.0 \%$ & - & $8.3 \%$ \\
\hline 便所及び洗面所 & $12.5 \%$ & - & $6.3 \%$ \\
\hline 浴室·脱衣室·シャワールーム & - & 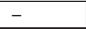 & $16.7 \%$ \\
\hline
\end{tabular}

表 11 具体的なヒヤリハットの内容とその時の状況

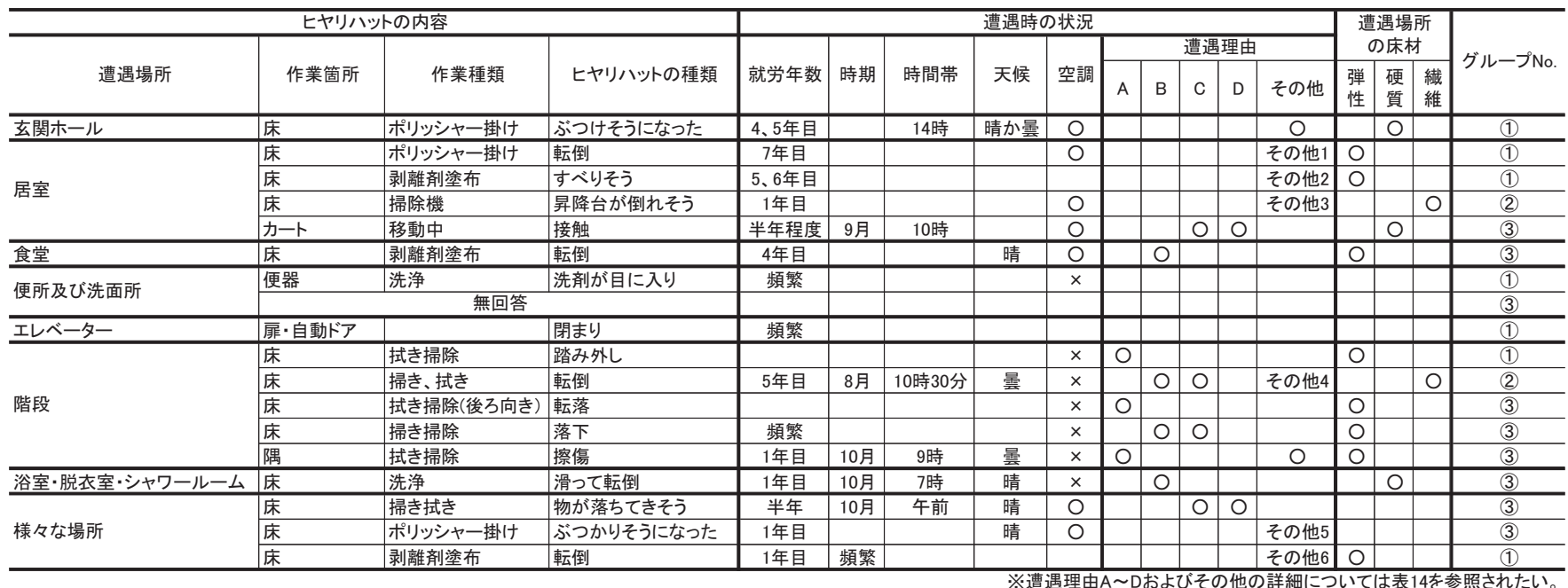

が発生しており、「居室」「階段」はすべてのグループでヒヤリハッ トが発生していることがわかる。

ここで、具体的なヒヤリハットの内容を発生場所別に表 11 に示 すが、作業箇所では 17 指摘のうち 13 指摘が「床」であり、「扉・ 自動ドア」「カート」「便器」「隅」がそれぞれ 1 指摘ずつ認められ る。さらに指摘の多い「床」を作業種類別にみるならば、13 指摘の うちワックス掛けの前に行う剥離剤塗布が 3 指摘、ポリッシャー掛 けが 3 指摘、拭き作業が 2 指摘、掃き拭き掃除が 2 指摘、掃き掃除、 洗浄、掃除機がそれぞれ 1 指摘であり、ワックス掛けや拭き掃除、 ポリッシャー掛けといった、ウェットクリーニングの実施時にヒヤ リハットが集中していることがわかる。

以上の分析から、ヒヤリハットは床のウェットクリーニングの実 施により、滑りやすくなっている場所や、階段のような段差のある 場所で発生していることを明らかにした。

\section{7. 業務災害の実態}

グループ(1)、（2)、（3)それぞれにおける清掃場所ごとの業務災害の
遭遇者率注 6) を算出した。結果を表 12 に示す。

グループ(1)では、「居室」「便所及び洗面所」の 2 箇所で業務災害 の遭遇が認められ、グループ(2)では、「玄関ホール」の 1 箇所で、 グループ(3)では、「居室」「便所及び洗面所」「浴室・脱衣室・シャワ ールーム」の 3 箇所で業務災害に遭遇している。ここで、具体的な 業務災害の内容を災害場所別に表 13 に示すが、作業箇所では 8 指 摘のうち、「床」が 4 指摘、「扉・自動ドア」が 2 指摘、「浴槽」「ゴ ミ箱」がそれぞれ 1 指摘である。さらに指摘の多い「床」を作業種 類別にみるならば、ワックス掛けや拭き掃除を行っている際に業務 災害に遭遇していることがわかる。

ここでグループ(1)、(3)で指摘が認められる「居室」について、表 13 および表 14 に示した災害時の状況の発生理由を併せてみるなら ば、「仕事に慣れていなかったため」「掃除に必死になっていて気付 かなかった」「いつもはないものがあったため気付かなかった」など が理由として挙げられている。

以上の分析から、業務災害は清掃場所の状態が変化した時や、作 業員が作業場所に配置されて間もない時など、清掃場所の状態の把

表 13 具体的な業務災害の内容とその時の状況

\begin{tabular}{|c|c|c|c|c|c|c|c|c|c|c|c|c|c|c|c|c|c|c|}
\hline \multicolumn{5}{|c|}{ 災害内容 } & \multicolumn{10}{|c|}{ 災害時の状況 } & \multirow{2}{*}{\multicolumn{3}{|c|}{$\begin{array}{c}\text { 災害場所 } \\
\text { の床材 }\end{array}$}} & \multirow{3}{*}{ グループNo. } \\
\hline \multirow[b]{2}{*}{ 災害場所 } & \multirow[b]{2}{*}{ 作業箇所 } & \multirow[b]{2}{*}{ 作業種類 } & \multirow[b]{2}{*}{ 災害の種類 } & \multirow[b]{2}{*}{ ケガの種類 } & \multirow[b]{2}{*}{ 就労年数 } & \multirow[b]{2}{*}{ 時期 } & \multirow[b]{2}{*}{ 時間帯 } & \multirow[b]{2}{*}{ 天候 } & \multirow[b]{2}{*}{ 空調 } & \multicolumn{5}{|c|}{ 発生理由 } & & & & \\
\hline & & & & & & & & & & A & B & c & D & その他 & $\begin{array}{l}\text { 弾 } \\
\text { 性 } \\
\end{array}$ & $\begin{array}{l}\text { 硬 } \\
\text { 質 }\end{array}$ & $\begin{array}{l}\text { 緎 } \\
\text { 維 }\end{array}$ & \\
\hline 玄関ホール & 屝·自動ドア & センサーを止めガラス拭き & 手を挟み & & 1 年目 & & & & $\mathrm{O}$ & & & & & その他3 & & & $\mathrm{O}$ & (2) \\
\hline \multirow{5}{*}{ 居室 } & ゴミ箱 & ごみ収集 & 割れ物 (ガラス) & 手を切った & 1年目 & & 9時 & & 0 & & & & & その他7 & 0 & & & (1) \\
\hline & 床 & 拭き掃除 & 車のトランクで & 頭を打った & 1年目 & & 9時30分 & 晴 & & & & & & その他8 & 0 & & & (1) \\
\hline & 床 & しやがんでものを取る & & ぎっくり腰 & 2年目 & 10月3日 & 8時30分 & 晴 & & & & 0 & & & 0 & & & (1) \\
\hline & 床 & ワックス掛け & 転倒 & 手を打った & 9年目 & 7 & 朝 & 晴 & 0 & & & & & その他2 & 0 & & & (1) \\
\hline & 床 & モップ & 椅子 & 目をうった & 2年半 & 夏期 & 11時 & 晴 & & & & & & & & & & (3) \\
\hline \multirow{2}{*}{ 便所及び洗面所 } & 扉·自動ドア & 閉める & 挟み & 指を切った & 10年目 & 11 & 9時30分 & 曇 & $x$ & $\mathrm{O}$ & & & & & $\mathrm{O}$ & & & (1) \\
\hline & & 拭き掃除 & 転倒 & 肩をはずした & 入ってすぐ & & & & & & & & & & $\mathrm{O}$ & & & (3) \\
\hline $\begin{array}{l}\text { 浴室·脱衣室· } \\
\text { シャワールーム }\end{array}$ & 浴槽 & 洗い & & ぎっくり腰 & 2年半 & 夏期 & 11時 & 晴 & $x$ & & & & O & その他9 & 0 & & & (3) \\
\hline
\end{tabular}


握レベルが低い時に発生していることを明らかにした。

\section{8. ヒヤリハットと業務災害の関連}

ここでは業務災害につながると考えられているヒヤリハットと、 業務災害の関連について検討するため、横軸にヒヤリハットの遭遇 者率を、縦軸に業務災害の遭遇者率をとり、各グループにおいて両 者が発生している清掃場所を布置した。結果を図 6 に示す。なお、 1 点鎖線で示したラインはヒヤリハットと業務災害の遭遇者率が一 致する点を示しており、ヒヤリハットと業務災害の関連をみる基準 と捉えることができる。すなわち、1 点鎖線付近はヒヤリハットの 遭遇者率と業務災害の遭遇者率が一致する (連動型)、1 点鎖線の上 部は、ヒヤリハットの遭遇者率よりも業務災害の遭遇者率が高い区 分 (業務災害突発型)、1 点鎖線の下部はヒヤリハットの遭遇者率の ほうが業務災害の遭遇者率よりも高い区分（ヒヤリハット蓄積型） と解釈できる。

図 6 をみるならば、ヒヤリハットと業務災害の両者が発生してい るすべての清掃場所、寸なわちグループ(1)における「居室」「便所及 び洗面所」、グループ(3)「居室」「便所及び洗面所」「浴室・脱衣室・ シャワールーム」はヒヤリハットの遭遇者率と業務災害の遭遇者率 が一致する（連動型）であることがわかる。

\section{9. 結語}

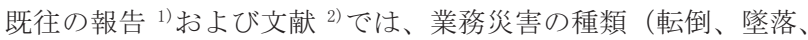
転落等）およびそれぞれの発生件数は明らかにされているが、災害 発生の一要因と考えられる作業環境の実態と業務災害発生の関係に ついての論考は十分になされていない。そこで本研究では、業務災 害の発生抑制をはかるためには、まずこれらの関係を明らかにする 必要があるといった考えの下、ビルメンテナンス業のなかでも業務 災害の発生が集中している清掃業務を対象として、清掃作業環境の 実態と業務災害発生の関係について分析した。具体的には、ビルメ ンテナンス業者が清掃業務を受託している建物の清掃作業環境の実 態を示したうえで、対象建物を作業環境特性により類型化し、それ ぞれの作業環境における精神的、身体的な作業員負荷を明らかにし た。さらに建物清掃における業務災害の発生抑制を目的として、清 掃作業中に発生する業務災害およびヒヤリハットの関連について検 討した。

第 1 段階の検討として、ビルメンテナンス業者における受託建物 の清掃作業環境に関する調查結果に基づき、回答が得られた 242 建 物のうち、サンプル数に偏りが小さく、かつ作業環境特性を表す 10 項目についてすべて回答が得られた 124 件を対象に、数量化理論第

表 14 災害状況の理由一覧

\begin{tabular}{c|l}
\hline 略号 & \multicolumn{1}{|c}{ 災害理由 } \\
\hline 理由 $A$ & 時間がなく焦っていたため \\
\hline 理由B & 体の自由がきかなかったため \\
\hline 理由C & 疲れていたため \\
\hline 理由D & 周辺環境が悪かったため \\
\hline その他1 & 洗剂で滑りやかった \\
\hline その他2 & 自分の不注意 \\
\hline その他3 & 仕事に慣れていなかったため \\
\hline その他4 & 体調不良 \\
\hline その他5 & 注意不足、経験不足 \\
\hline その他6 & すべりやすいい \\
\hline その他7 & いつもはないものがあったため気付かなかった \\
\hline その他8 & 掃除に必死になっていて気付かなかった \\
\hline その他9 & ユニットがせまく動きにくく腰をひねった \\
\hline
\end{tabular}

III類による解析を適用した。さらに既往研究 ${ }^{4)}$ にて適用した分析手 法に基づき、第 I 軸および第 II 軸のサンプルスコアを用いて、ウォ ード法によるクラスター分析により類型化を実施した結果、124物 件は「(1)旧中規模建物」「(2)新小規模建物」「(3)大規模建物」の 3 グ ループに分類された。

第 2 段階の検討として、類型化された各グループに含まれる建物 において、実際に清掃作業に従事している清掃作業員を対象として、 面接形式により実施した清掃作業員の身体・精神負荷等に関する調 查結果から、精神的疲労、身体的疲労、ヒヤリハット、業務災害そ れぞれの実態を明らかにした。

分析により、精神的疲労は、「污れに対する疲労」と「建物利用者 への配慮による疲労」に大別され、「污れに対する疲労」は各清掃場 所における特異な污れが要因となっていることを明らかにした。さ らに精神的疲労を感じる場所の分布は、建物利用者への配慮、寸な わち利用者との遭遇場所と関連が認められることを明らかにした。 また清掃作業員における身体的疲労は、「作業時間」の長短が起因し ており、対象が大規模になるにつれ、作業員に疲労が認められる傾 向があることを明らかにした。

つぎに業務災害の発生につながると考えられるヒヤリハットにつ いて分析した結果、ヒヤリハットは、ウェットクリーニングの実施 によりすべりやすくなっている床や、段差のある場所で発生してい ることを明らかにした。また業務災害は、清掃場所の状態が変化し た時や作業員が作業場所に配置されて間もない時など、清掃場所の 状態の把握レベルが低い時に発生していることを明らかにした。

さらに建物清掃における業務災害の発生抑制を目的として、業務 災害につながると考えられるヒヤリハットと、業務災害の関連につ いて分析した結果、グループを問わずウェットクリーニングを実施 する清掃場所は、ヒヤリハットの遭遇者率と業務災害の遭遇者率の 一致する「連動型」であることを明らかにした。

最後に、本研究の成果を踏まえ今後の展開について述べる。 本研究の目的である、業務災害の発生抑制を達成するためには、 「連動型」に含まれる清掃場所の重点管理が必要であるが、それを 実施するためには、例えば、清掃作業環境の改善、作業員の教育強 化、作業員年齢の適正化等、様々な取り組みが必要となる。しかし、

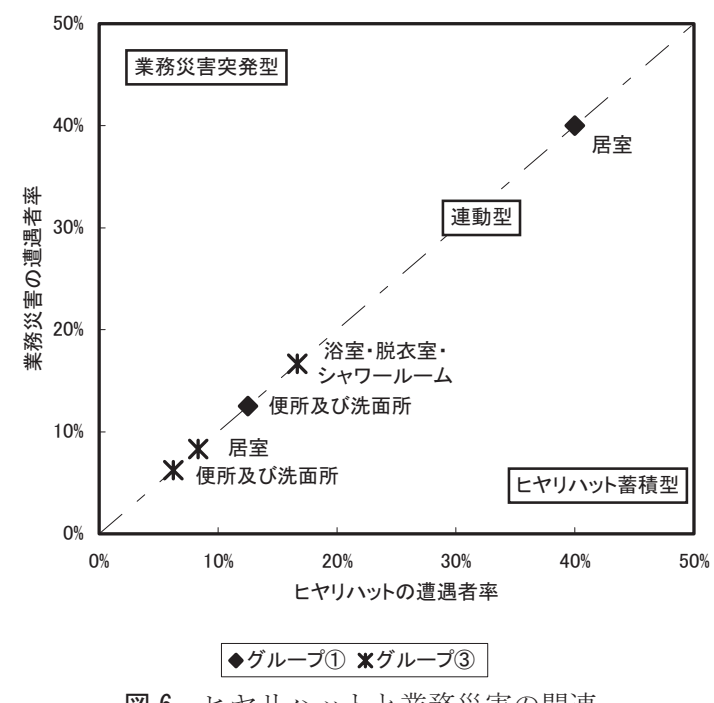

図 6 ヒヤリハットと業務災害の関連 
これらの改善は清掃コストに反映されることが予測され、業務災害 の発生抑制を達成するためには、受託者側の企業努力にあわせ、発 注者側の理解も不可欠である。

今後の展開としては、発注者側に対して本研究の成果を示したう えで、発注者側における業務災害の発生抑制に対する認識、および その改善実施に対する姿勢を把握する必要があると考える。

\section{謝辞}

調査研究に多大なご協力をいただいた調查対象建物の関係者の 方々に謝意を表します。また本研究は、広島工業大学 2006 年度卒 論生、松尾浩志君、2007 年度卒論生、重原綾乃君に協力いただきま した。ここに謝意を表します。

\section{注}

注 1）本研究で定義する公共施設とは、公共が所有、または管理している、庁 舎、学校、病院、集会所等の公益的な建物を指寸。

注 2）協会をとおして 124 建物の管理会社、計 24 社に調查を依頼したが、建 物所有者との関係などにより、11 建物のみの調查となっている。

注 3）本研究では、文献 5)を参考に清掃場所を分類し、建物の稼働時に建物
利用者が常時居る部屋を「居室」として分類した。

注 4）実施者率とは、各グループにおける回答者のうち、各清掃場所において 清掃作業を実施している人の割合を示す

注 5）体感者率とは、各清掃場所における作業実施者のうち、「感じる」「少 し感じる」「あまり感じない」「感じない」の 4 段階で回答を求めた疲 労度について、「感じる」「少し感じる」と回答した人の割合を示す。

注 6）遭遇者率とは、各清掃場所における作業実施者のうち、ヒヤリハットに 遭遇した人の割合もしくは業務災害に遭遇した人の割合を示す。

\section{参考文献}

1）全国ビルメンテナンス協会，労働災害業種別報告，2004

2）正田浩三，垣鍔 直，杖先寿里，清澤裕美：ビル清掃業務に従事する中 高年就労者の業務災害に関する調査, 日本建築学会環境系論文集, No.568, pp.89-96, 2003.6

3）永冨太一，佐藤誠治，小林祐司，姫野由香，杜 守帥：用途地域に抢け る土地利用混合度に関する調査・分析(その 2), 日本建築学会学術講演 梗概集，F-1 冊，pp.657-658，2005.9

4）佐藤隆良，杉田 洋，村川三郎，西名大作，平賀 慎：街区公園におけ る利用者評価による清掃品質管理手法に関する研究, 日本建築学会計画 系論文集，No.607，pp.141-148，2006.9

5）国土交通省大臣官房官庁営繥部編，建築保全業務共通仕様書，(財)建築保 全センター，2003

（2008年 3 月10日原稿受理，2008年 9 月10日採用決定） 